\title{
DÉL-DUNÁNTÚL OKTATÁSI ÉS KULTURÁLIS HELYZETÉNEK VIZSGÁLATA ${ }^{20}$
}

\author{
Szűcs Krisztián ${ }^{2}$ \\ ${ }^{2} \mathrm{PhD}$ hallgató, Pécsi Tudományegyetem Közgazdaságtudományi Kar, Regionális Politika és Gazdaságtan \\ Doktori Iskola, Pécs
}

\begin{abstract}
SUMMARY
Within the framework of the European Union's Social Renewal Operational Programme "TÁMOP" in which the South Transdanubian development opportunities are being researched, we placed special emphasis on the educational and cultural situation which essentially forms the basics of the quality of the human resource. The importance of it is clear as a developing economy can only emerge if professional human resource that can supply and operate the demand is available in the region. The development of an educational system that meets the needs of the economic system has been failed so far. Some examples can prove this statement: the lack of experts had been the reason for new industries not to come to the region. The examination of the educational and cultural situation is also important because the region centres have had long history of education which can be an economic potential as they attract students from other regions.
\end{abstract}

Kulcsszavak: Dél-Dunántúli régió, oktatás, iskolai végzettség, kultúra, könyvtárak

\section{BEVEZETÉS}

A Pécsi Tudományegyetem Közgazdaságtudományi Kar által végzett TÁMOP kutatás a Dél-Dunántúl gazdasági erőforrásainak vizsgálatával és annak feltárásával foglalkozik. A kutatás első fázisában a régió erőforrásainak feltérképezése történt. A helyzetfelmérés során többek között felmértük Dél-Dunántúl oktatási és kulturális helyzetét is. A két terület fontosságát az indokolja, hogy a korszerü gazdaság igényeivel összhangban kell lennie az oktatási rendszernek is, hogy képzett szakemberek kerüljenek ki a munkaerőpiacra. A régió nem túl jó adottságai megnehezítik az oktatási rendszer fejlesztését, amiben szerepet játszik a településszerkezet, valamint a rossz közlekedési infrastruktúra is. Mivel a régió megyei központjai jelentős oktatási és kulturális múlttal rendelkeznek, ezért vonzó képzési lehetőséget jelentenek a más térségből jövő hallgatók számára. Dél-Dunántúl kultúrtörténeti értékei az országban kiemelkedöek, ami idegenforgalmi vonzerőt és egyben jelentős gazdasági alapot jelent a térségnek. Ezek azok az okok, ami miatt az oktatási és a kulturális tényezőket a gazdaságival azonos szinten kezeljük.

\section{A DÉL-DUNÁNTÚLI RÉGIÓ TELEPÜLÉSSZERKEZETE}

Az oktatási és kulturális helyzetet kialakulásában meghatározó szerepe van a térség településszerkezetének is. A régió három megyéjében (Baranya, Somogy, Tolna) összesen 25 kistérség és 655 település helyezkedik el. A térség településhálózata jellemzöen aprófalvas szerkezetü. A városi népesség aránya 58,8\%, ami elmarad a 69,4\%-os országos átlagtól. A népsürüség is a Dél-dunántúli régióban a legalacsonyabb $67 \mathrm{fö} / \mathrm{km} 2$, ami lényegesen kevesebb az országos $108 \mathrm{fö} / \mathrm{km} 2$-es átlagnál. (1. táblázat) Meg kell még említeni a népesség természetes fogyását $(5,8 \%)$, ami a legnagyobb az országban. (Buday-Sántha A. 2011)

\footnotetext{
${ }^{20}$ A tanulmány a TÁMOP-4.2.1. B-10/2/KONV-2010-0002, A Dél-Dunántúli régió egyetemi versenykẻpességének fejlesztése projekt, Dél-Dunántúl gazdasági erőforrásainak feltárása és fejlesztési lehetőségek meghatározása c. alprojekt keretében készült. Kutatás vezetōje: dr. Buday-Sántha Attila
} 


\section{1. táblázat: Dél-dunántúli régió általános jellemzõi}

\begin{tabular}{|l|c|c|c|c|c|c|c|}
\hline & $\begin{array}{c}\text { Terület } \\
\text { (ba) }\end{array}$ & $\begin{array}{c}\text { Ország } \\
\text { területének } \\
\%-b a n\end{array}$ & $\begin{array}{c}\text { Lakosság } \\
\text { (fó) }\end{array}$ & $\begin{array}{c}\text { Ország } \\
\text { népességének } \\
\% \text {-ban }\end{array}$ & $\begin{array}{c}\text { Településszám } \\
\text { (db) }\end{array}$ & $\begin{array}{c}\text { Ország } \\
\text { településeinek } \\
\% \text {-ban }\end{array}$ & $\begin{array}{c}\text { Népsúrüség } \\
\text { (fó/km2) }\end{array}$ \\
\hline Baranya megye & 442960 & $4,76 \%$ & 393758 & $3,93 \%$ & 301 & $9,48 \%$ & 88,89 \\
\hline Somogy megye & 603586 & $6,49 \%$ & 320578 & $3,20 \%$ & 245 & $7,72 \%$ & 53,11 \\
\hline Tolna megye & 370323 & $3,98 \%$ & 233650 & $2,33 \%$ & 109 & $3,43 \%$ & 63,09 \\
\hline Dél-Dunántúl & 1416869 & $15,23 \%$ & 947986 & $9,47 \%$ & 655 & $20,64 \%$ & 66,91 \\
\hline Magyarország & 9302744 & $100 \%$ & 10014324 & $100 \%$ & 3174 & $100 \%$ & 107,64 \\
\hline
\end{tabular}

Forrás: KSH Évkönyv (2010) alapján saját szerkesztés, 2012

Ha a régió gazdasági helyzetét nemzetközi szinten szeretnénk meghatározni, akkor azt mondhatjuk, hogy az Európai Unió 271 NUTS-2 régiója közül a Dél-dunántúli régió a gazdasági teljesítménye alapján a 253. A 25 kistérség közül 18 hátrányos helyzetü és ebböl pedig 9 a leghátrányosabb helyzetü. Ennek az egyik negatív hozadéka a magas munkanélküliségi ráta, amely meghaladja az országos 11\%-ot (2011). Ebből következően magas a munkaeró piaci túlkínálat, ami azt eredményezi, hogy 15-20\%-kal alacsonyabbak a bérek az országos átlagnál. Megállapítható tehát, hogy a kritikus foglalkoztatási helyzet miatt fontos a képzett munkaerö és ebből következően az oktatás szerepe kiemelt jelentőségü. Mivel a régióban alacsony a népességszám, alacsony a népsürüség és sok az aprófalu, ezek nem kedveznek egy minöségi oktatási rendszer kialakításának. Ezt a folyamatot tovább erösíti a rossz infrastrukturális ellátottság. A vonalas infrastruktúra (közút, vasút) fejlesztésében alapvető változásokra nem lehet számítani a közeljövőben. A gazdaságfejlesztés a megyei központokban koncentrálódik, amelyeknek az elérhetősége rossz és a megyei központok közötti közutak alacsony színvonalúak. Hiányosak a falusi összekötő utak és a másodrendü útvonalak közötti kapcsolatok. (Buday-Sántha A. 2011)

\section{OKTATÁSI HELYZETKÉP}

A gazdasági helyzet javítása érdekében is szükséges lenne egy jól müködő oktatási rendszer kialakitására és annak összehangolására a munkaerő piaci igényekkel. Mivel a térség komoly oktatási múlttal rendelkezik, ezért célszerü lenne kihasználni az abban rejlő potenciált. Ennek meg kellene jelennie a szakképzés és a felsöoktatás szintjén is. A hazai oktatási rendszerben a munkába lépés, illetve a tanulmányok felsö szintủ folytatásának a feltételét a középfokú oktatás testesíti meg, ezért a vizsgálatunk is erre irányul.

A régiót az országos adatokhoz viszonyítva vizsgáljuk, akkor látható, hogy a szakiskolában tanulók 11,7\%-a tanul a Dél-Dunántúlon, míg szakközépiskolában 7,9\% és gimnáziumban pedig $9,2 \%$. (2. táblázat) A szakiskolai oktatás viszonylag erősebb a többi középfokú oktatási formához képest.

2. táblázat: Középfokú képzésben résztvevő tanulók számának alakulása 2010

\begin{tabular}{|l|c|c|c|c|c|c|}
\hline & Szakiskola & $\begin{array}{c}\text { Régió-ország } \\
\text { viszony (\%) }\end{array}$ & Szakközépiskola & $\begin{array}{c}\text { Régió-ország } \\
\text { viszony (\%) }\end{array}$ & Gimnázium & $\begin{array}{c}\text { Régió-ország } \\
\text { viszony (\%) }\end{array}$ \\
\hline Dél-Dunántúl & 16246 & $11,7 \%$ & 18990 & $7,9 \%$ & 18294 & $9,2 \%$ \\
\hline Magyarország & 139237 & $100 \%$ & 240364 & $100 \%$ & 198700 & $100 \%$ \\
\hline
\end{tabular}

Forrás: KSH évkönyv (2010) alapján sajảt szerkesztés, 2012 
Ha ugyan ezt megyei szinten is tanulmányozzuk, akkor megállapítható, hogy Baranya megye $(36 \%)$ és Somogy megye $(36,4 \%)$ viszonylag kiegyenlített képet mutat, míg Tolna megye elmarad $(27,6 \%)$ a szakiskolai oktatás tekintetében. (3. táblázat) A szakközépiskolai oktatás helyzete arányaiban viszonylag megegyezik a szakiskolai helyzettel. Baranya megye $(37,7 \%)$ és Somogy megye $(36,8 \%)$ között nagyon nagy különbség nincsen, viszont ebben az esetben is Tolna megye marad el $(25,5 \%)$. A gimnáziumi oktatás helyzete egyértelmüen eltérő. Baranya megye képviseli a legnagyobb arányú gimnáziumi oktatást (46\%) és Somogy megye $(27,5 \%)$, illetve Tolna megye $(26,5 \%)$ között nagyarányú különbség nincsen.

\section{3. táblázat: Középfokú képzésben tanulók számának alakulása régió-megyék viszonyában 2010}

\begin{tabular}{|l|c|c|c|c|c|c|}
\hline & $\begin{array}{c}\text { Szakiskola } \\
\text { (fö) }\end{array}$ & $\begin{array}{c}\text { Megyék helyzete } \\
\text { a régióban (\%) }\end{array}$ & $\begin{array}{c}\text { Szakközépiskola } \\
\text { (fö) }\end{array}$ & $\begin{array}{c}\text { Megyék helyzete } \\
\text { a régióban (\%) }\end{array}$ & $\begin{array}{c}\text { Gimnázium } \\
\text { (fö) }\end{array}$ & $\begin{array}{c}\text { Megyék helyzete } \\
\text { a régióban (\%) }\end{array}$ \\
\hline Baranya megye & 5851 & $36,0 \%$ & 7163 & $37,7 \%$ & 8421 & $46,0 \%$ \\
\hline Somogy megye & 5915 & $36,4 \%$ & 6993 & $36,8 \%$ & 5031 & $27,5 \%$ \\
\hline Tolna megye & 4480 & $27,6 \%$ & 4834 & $25,5 \%$ & 4842 & $26,5 \%$ \\
\hline Dél-Dunántúl & 16246 & $100 \%$ & 18990 & $100 \%$ & 18294 & $100 \%$ \\
\hline
\end{tabular}

Forrás: KSH évkönyv (2010) alapján saját szerkesztés, 2012

A régió belsỏ szerkezetét vizsgálva egy viszonylag homogén képet láthatunk. (4. táblázat) A Dél-Dunántúlon tanulók 30,35\%-a tanul szakiskolában, míg szakközépiskolában $35,48 \%$ és gimnáziumban pedig $34,2 \%$.

\section{4. táblázat: Középfokú intézményekben tanulók számának aránya 2010}

\begin{tabular}{|l|c|c|c|c|c|c|c|c|}
\hline & $\begin{array}{c}\text { Szakiskola } \\
\text { (fó) }\end{array}$ & $\begin{array}{c}\text { Régió } \\
\text { belsó } \\
\text { szerkezete } \\
(\%)\end{array}$ & $\begin{array}{c}\text { Szakközépiskola } \\
\text { (fó) }\end{array}$ & $\begin{array}{c}\text { Régió } \\
\text { belsó } \\
\text { szerkezete } \\
(\%)\end{array}$ & $\begin{array}{c}\text { Gimnázium } \\
\text { (fó) }\end{array}$ & $\begin{array}{c}\text { Régió } \\
\text { belsõ } \\
\text { szerkezete } \\
(\%)\end{array}$ & $\begin{array}{c}\text { Középfokú } \\
\text { intézmények } \\
(\text { fó) }\end{array}$ & $\begin{array}{c}\text { Régió } \\
\text { belsó } \\
\text { szerkezete } \\
(\%)\end{array}$ \\
\hline $\begin{array}{l}\text { Baranya } \\
\text { megye }\end{array}$ & 5851 & $27,30 \%$ & 7163 & $33,42 \%$ & 8421 & $39,29 \%$ & 21435 & $100 \%$ \\
\hline $\begin{array}{l}\text { Somogy } \\
\text { megye }\end{array}$ & 5915 & $32,97 \%$ & 6993 & $39,98 \%$ & 5031 & $28,05 \%$ & 17939 & $100 \%$ \\
\hline $\begin{array}{l}\text { Tolna } \\
\text { megye }\end{array}$ & 4480 & $31,65 \%$ & 4834 & $34,15 \%$ & 4842 & $34,20 \%$ & 14156 & $100 \%$ \\
\hline $\begin{array}{l}\text { Dél- } \\
\text { Dunántíl }\end{array}$ & 16246 & $30,35 \%$ & 18990 & $35,48 \%$ & 18294 & $34,18 \%$ & 53530 & $100 \%$ \\
\hline
\end{tabular}

Forrás: KSH évkönyv (2010) alapján saját szerkesztés, 2012

Ha ezt megyei bontásban is tárgyalni szeretnénk, akkor elmondható, hogy Baranya megyében egyértelmüen a gimnáziumi oktatás a legerösebb $(39,29 \%)$, míg a szakközépiskolai oktatás a második legerősebb $(33,42 \%)$ és a szakiskolai oktatás a legutolsó $(27,3 \%)$. Somogy megyében viszont a szakközépiskolai oktatásban tanulnak a legtöbben $(39,98 \%)$ és utána következik a szakiskolai oktatás 32,97\%-kal, míg a gimnáziumi oktatás a leggyengébb $(28,05 \%)$. Tolna megye a legkiegyenlítettebb. Itt a gimnáziumi oktatás $(34,2 \%)$ és a szakközépiskolai oktatás $(34,15 \%)$ szinte azonos arányt képvisel és a szakiskolai képzés marad el $(31,65 \%)$.

A vizsgálatunkat, ha kiterjesszük a lakosság és az adott iskola típusban tanulók arányára, akkor érdekes képet kapunk. Megfigyelhető, hogy szakiskolai oktatás tekintetében mind a régió, mind pedig a három megye az országos átlag $(1,39 \%)$ felett van. (5. táblázat) 


\section{5. táblázat: Középfokú intézményekben tanulók számának aránya népességhez viszonyítva 2010}

\begin{tabular}{|l|c|c|c|c|c|c|c|}
\hline & $\begin{array}{c}\text { Lakosság } \\
\text { (fó) }\end{array}$ & $\begin{array}{c}\text { Szakiskola } \\
\text { (fö) }\end{array}$ & $\begin{array}{c}\text { Szakiskolások } \\
\text {-lakosság } \\
\text { arány (\%) }\end{array}$ & $\begin{array}{c}\text { Szakközépiskola } \\
\text { (fó) }\end{array}$ & $\begin{array}{c}\text { Szakközépiskol } \\
\text { ások-lakosság } \\
\text { arány (\%) }\end{array}$ & $\begin{array}{c}\text { Gimnázium } \\
\text { (fó) }\end{array}$ & $\begin{array}{c}\text { Gimnazisták } \\
\text {-lakosság } \\
\text { arány (\%) }\end{array}$ \\
\hline $\begin{array}{l}\text { Baranya } \\
\text { megye }\end{array}$ & 393758 & 5851 & $1,49 \%$ & 7163 & $1,82 \%$ & 8421 & $2,14 \%$ \\
\hline $\begin{array}{l}\text { Somogy } \\
\text { megye }\end{array}$ & 320578 & 5915 & $1,85 \%$ & 6993 & $2,18 \%$ & 5031 & $1,57 \%$ \\
\hline $\begin{array}{l}\text { Tolna } \\
\text { megye }\end{array}$ & 233650 & 4480 & $1,92 \%$ & 4834 & $2,07 \%$ & 4842 & $2,07 \%$ \\
\hline Dél-Dunántúl & 947986 & 16246 & $1,71 \%$ & 18990 & $2,00 \%$ & 18294 & $1,93 \%$ \\
\hline Magyarország & 10014324 & 139237 & $1,39 \%$ & 240364 & $2,40 \%$ & 198700 & $1,98 \%$ \\
\hline
\end{tabular}

Forrás: KSH évkönyv (2010) alapján saját szerkesztés, 2012

Az országos átlag a szakközépiskolában tanulók figyelembevételével 2,40\% és ebben van egy kis lemaradása a régiónak. Míg a szakiskolai oktatásban többen tanulnak Dél-Dunántúlon az országos adatokhoz viszonyítva, addig a szakközépiskolákban kevesebben. A gimnáziumban tanulóknál nem egyértelmủ a helyzet. A régió arányaiban lemaradást mutat $(1,93 \%)$ az országos adatokhoz képest $(1,98 \%)$, de megyei szinten Baranya megye $(2,14 \%)$ és Tolna megye $(2,07 \%)$ fölötte van és Somogy megye mutat lemaradást $(1,57 \%)$.

Ezek után vizsgáljuk meg az egyes iskolatípusokat a középfokú oktatásban, a Déldunántúli régióban.

\subsection{SZAKISKOLAI TANULÓK SZÁMÁNAK ALAKULÁSA 1990 ÉS 2010 KÖZÖTT}

A szakiskolai oktatás nem a legjelentősebbként képviselteti magát, amit jól mutat, hogy országos viszonylatban (2010) a diákok 11,7\%-a tanult szakiskolákban ebben a régióban. Ez az országos számokkal összhangban van. A Déldunántúli régiót tekintve közel kiegyensúlyozott a megyei szintü szakiskolai oktatás. (6. táblázat) A szakiskolai oktatás területi megoszlása hasonló, mint a szakközépiskolai oktatásé:

\section{6. táblázat: A nappali képzésben résztvevő szakiskolai tanulók számának alakulása} 1990 és 2010 között

\begin{tabular}{|c|c|c|c|c|c|c|}
\hline & \multicolumn{3}{|c|}{$\begin{array}{l}\text { Nappali képzésben résztvevõ szakiskolai tanulók száma } \\
\text { (fô) }\end{array}$} & \multicolumn{3}{|c|}{ Változás 1990-2010 } \\
\hline & 1990 & 2001 & 2010 & $\begin{array}{l}20011990 \\
\% \text {-ban }\end{array}$ & $\begin{array}{c}20102001 \\
\%-\text { ban }\end{array}$ & $\begin{array}{l}20101990 \\
\% \text {-ban }\end{array}$ \\
\hline Baranya megye & 8724 & 5383 & 5851 & $61,7 \%$ & $108,7 \%$ & $67,1 \%$ \\
\hline Somogy megye & 7207 & 5539 & 5915 & $76,9 \%$ & $106,8 \%$ & $82,1 \%$ \\
\hline Tolna megye & 5161 & 4238 & 4480 & $82,1 \%$ & $105,7 \%$ & $86,8 \%$ \\
\hline Dél-Dunántúl & 21092 & 15160 & 16246 & $71,9 \%$ & $107,2 \%$ & $77,0 \%$ \\
\hline Magyarország & 225356 & 130545 & 139237 & $57,9 \%$ & $106,7 \%$ & $61,8 \%$ \\
\hline
\end{tabular}

Forrás: KSH évkönyvek $(1990,2000,2010)$ alapján saját szerkesztés, 2012

A régiót tekintve Pécsnek van a legnagyobb szívóhatása. Somogy és Tolna megyében valamelyest kiegyensúlyozottabb képet mutatnak a vidéki oktatási központok Baranya megyéhez képest. Az adatok azt mutatják, hogy a szakiskolai oktatás szerepe, jelentősége a rendszerváltás óta mind országos, mind pedig a vizsgált régió szintjén jelentősen 
leértékelödött, ami ellentmondásban van azzal, hogy mindenütt a gazdasági növekedést és a munkanélküliség csökkenését a betelepült ipartól várják. (Buday-Sántha A. 2011)

\subsection{SZAKKÖZÉPISKOLAI TANULÓK SZÁMÁNAK ALAKULÁSA 1990 ÉS 2010 KÖZÖTT}

A 2010-es évet vizsgálva megállapitható, hogy a szakközépiskolai diákok számának megoszlása 7,9\%-a volt az országos átlagnak és csökkenỏ tendenciát mutat. A három megye közül Baranyában jár a legtöbb diák szakközépiskolába. (7. táblázat)

7. táblázat: A nappali képzésben résztvevỏ szakközépiskolai tanulók számának alakulása 1990 és 2010 között

\begin{tabular}{|c|c|c|c|c|c|c|}
\hline & \multicolumn{3}{|c|}{$\begin{array}{l}\begin{array}{l}\text { Nappali képzésben résztvevố szakkōzépiskolai tanulók száma } \\
\text { (fô) }\end{array} \\
\end{array}$} & \multicolumn{3}{|c|}{ Változás 1990-2010 } \\
\hline & 1990 & 2001 & 2010 & $\begin{array}{c}20011990 \\
\% \text {-ban }\end{array}$ & $\begin{array}{c}20102001 \\
\% \text {-ban }\end{array}$ & $\begin{array}{c}20101990 \\
\% \text {-ban }\end{array}$ \\
\hline Baranya megye & 5643 & 7657 & 7163 & $135,7 \%$ & $93,5 \%$ & $126,9 \%$ \\
\hline Somogy megye & 5054 & 7054 & 6993 & $139,6 \%$ & $99,1 \%$ & $138,4 \%$ \\
\hline Tolna megye & 3745 & 7009 & 4834 & $187,2 \%$ & $69,0 \%$ & $129,1 \%$ \\
\hline Dél-Dunántül & 14442 & 21720 & 18990 & $150,4 \%$ & $87,4 \%$ & $131,5 \%$ \\
\hline Magyarország & 168445 & 238348 & 240364 & $141,5 \%$ & $100.8 \%$ & $142,7 \%$ \\
\hline
\end{tabular}

Forrás: KSH évkönyvek (1990, 2000, 2010) alapján saját szerkesztés, 2012

Azon belül is Pécsnek van elszívó hatása, jelentősebb vidéki oktatási központokról nem beszélhetünk Baranyában. Somogy megyében is a megyeszékhelynek van meghatározó szerepe (Kaposvár), de ebben a megyében már a vidéki oktatási centrumok jelentősebb potenciált képviselnek. Tolna megyében is Szekszárd, mint a megyeszékhely képviseli a legnagyobb oktatási központot. (Buday-Sántha A. 2011)

\subsection{GIMNÁZIUMI TANULÓK SZÁMÁNAK ALAKULẢSA 1990 ÉS 2010 KÖZÖTT}

Ha országos viszonylatban vizsgáljuk a gimnáziumi oktatást, akkor megfigyelhető, hogy folyamatosan nö a diákok száma. Ugyan akkor Dél-Dunántúlon csak a 10\%-a tanult a diákoknak az országos adatokhoz viszonyítva.

8. táblázat: A nappali képzésben résztvevõ gimnáziumi tanulók számának alakulása 1990 és 2010 között

\begin{tabular}{|c|c|c|c|c|c|c|}
\hline & \multicolumn{3}{|c|}{$\begin{array}{l}\text { Nappali képzésben résztvevõ } \\
\text { gimnáziumi tanulók száma (fỏ) }\end{array}$} & \multicolumn{3}{|c|}{ Változás 1990-2010 } \\
\hline & 1990 & 2001 & 2010 & $\begin{array}{c}20011990 \\
\% \text {-ban }\end{array}$ & $\begin{array}{c}20102001 \\
\% \text {-ban }\end{array}$ & $\begin{array}{c}20101990 \\
\% \text {-ban }\end{array}$ \\
\hline Baranya megye & 5227 & 8030 & 8421 & $153,6 \%$ & $104,9 \%$ & $161,1 \%$ \\
\hline Somogy megye & 3286 & 4622 & 5031 & $140,7 \%$ & $108,8 \%$ & $153,1 \%$ \\
\hline Tolna megye & 4064 & 4331 & 4842 & $106,6 \%$ & $111,8 \%$ & $119,1 \%$ \\
\hline Dél-Dunántúl & 12577 & 16983 & 18294 & $135,0 \%$ & $107,7 \%$ & $145,5 \%$ \\
\hline Magyarország & 123427 & 182687 & 198700 & $148,0 \%$ & $108,8 \%$ & $161,0 \%$ \\
\hline
\end{tabular}

Forrás: KSH évkönyvek (1990, 2000, 2010) alapján saját szerkesztés, 2012 
Ez a szám nem túl magas. Még a növekedés is csak 45\%-os volt az 1990-2010 közötti időszakban, ami jelentős lemaradás az országos növekedéshez képest. Ha megyei szinten vizsgáljuk az adatokat, akkor itt is heterogén képet mutat az oktatás területi megjelenése. Baranyában a régió diákjainak 43,6\%-a jár gimnáziumba, Somogyban 27,5\%-a, még Tolnában 26,5\%-a. (8. táblázat) Somogy és Tolna megyében közel azonos számban járnak gimnáziumba a diákok, de Baranyának a pécsi oktatás erőssége miatt nagyobb szerepe van. (Buday-Sántha A. 2011)

\section{KULTURÁLIS HELYZETKÉP}

Az oktatás mellett kiemelt fontosságú a kultúra kérdése is. A kutatásunkban a kultúra több szegmensét is megvizsgáltuk:

- a múzeumok és a közmủvelődés alakulása

- könyvtárak helyzete

- színházak, színházi elöadások vizsgálata

- mozitermek száma, mozielöadások látogatottsága

Mindegyik területet részletesen kielemeztük, de terjedelmi okok miatt jelen tanulmány a Dél-dunántúli régió könyvtárainak helyzetével foglalkozik. Mivel az oktatásban könyvtáraknak nagy szerepe van, ezért gondoltuk, hogy kiemelt jelentőségünek tekintjük. A könyvtárak elemzésénél négy szempontot vettünk figyelembe, amelyek a következők:

- A települési könyvtárak száma

- A települési könyvtárak egységeinek száma

- A települési könyvtárakból kölcsönzött könyvtári egységek száma

- A települési könyvtárak beiratkozott olvasóinak száma

A tanulmányban tartalmi és logikai szempontból két részre bontva elemeztünk:

- Könyvtárak és könyvtári állomány számának alakulása

- Könyvtárakba beiratkozottak és a kikölcsönzött könyvtári egységek számának alakulása

\subsection{KÖNYVTÁRAK HELYZETE A DÉL-DUNÁNTÚLON}

A TÁMOP kutatásunkban a könyvtárakat különböző szempontok szerint vizsgáltuk. A vizsgált időszak ebben az esetben is 1990 és 2010 között volt.

9. táblázat: A könyvtárak és könyvtári állomány számának alakulása 1990-20002010

\begin{tabular}{|c|c|c|c|c|c|c|c|c|}
\hline & \multicolumn{3}{|c|}{$\begin{array}{c}\text { A települési } \\
\text { könyvtárak száma } \\
\text { (db) }\end{array}$} & \multirow{2}{*}{ 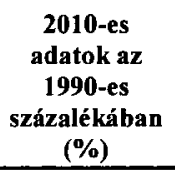 } & \multicolumn{3}{|c|}{$\begin{array}{l}\text { A települési könyvtárak } \\
\text { egységeinek száma (db) }\end{array}$} & \multirow{2}{*}{$\begin{array}{c}\text { 2010-es } \\
\text { adatok az } \\
\text { 1990-es } \\
\text { százalékában } \\
(\%) \\
\end{array}$} \\
\hline & 1990 & 2000 & 2010 & & 1990 & 2000 & 2010 & \\
\hline Baranya megye & 312 & 239 & 247 & $79,20 \%$ & 2071640 & 2105408 & 1939038 & $93,60 \%$ \\
\hline Somogy megye & 296 & 240 & 234 & $79,10 \%$ & 1962813 & 2098034 & 2206663 & $112,40 \%$ \\
\hline Tolna megye & 130 & 105 & 109 & $83,80 \%$ & 1393427 & 1530823 & 1324516 & $95,10 \%$ \\
\hline Dél-Dunántúl & 738 & 584 & 590 & $79,90 \%$ & 5427880 & 5734265 & 5470217 & $100,80 \%$ \\
\hline Magyarország & 4163 & 2845 & 2966 & $71,20 \%$ & 40897431 & 44489957 & 43784645 & $107,10 \%$ \\
\hline
\end{tabular}

Forrás: KSH évkönyvek (1990, 2000, 2010) alapján saját szerkesztés, 2012 
A régióban a könyvtáraknak komoly kulturális szerepe van. Országos szinten a könyvtárak számában 29\%-o csökkenés volt tapasztalható, még Dél-Dunántúlon ez a szám csak $20 \%$ volt. (9. táblázat) Fontos megemlíteni, hogy bár sok esetben csökkent a kỏnyvtári egységek száma, a koncentrációjuk viszont nőtt. Sok hátrányos helyzetű településen pedig növekedés volt tapasztalható.

A régióban a könyvtárak számának 20\%-os csökkenését lényegesen meghaladja a beiratkozott olvasók számának a csökkenése $(-30 \%)$.

10. táblázat: Könyvtárakba beiratkozottak és a kikölcsönzött könyvtári egységek számának alakulása 1990-2000-2010

\begin{tabular}{|c|c|c|c|c|c|c|c|c|}
\hline & \multicolumn{3}{|c|}{$\begin{array}{c}\text { A települési könyvtárakból } \\
\text { kölcsönzött könyvtári egységek } \\
\text { száma (db) }\end{array}$} & \multirow{2}{*}{$\begin{array}{c}2010-e s \\
\text { adatok az } \\
\text { 1990-es } \\
\text { százalékában } \\
(\%) \\
\end{array}$} & \multicolumn{3}{|c|}{$\begin{array}{c}\text { A települési könyvtárak } \\
\text { beiratkozott olvasóinak } \\
\text { száma (db) }\end{array}$} & \multirow{2}{*}{$\begin{array}{c}2010 \text {-es } \\
\text { adatok az } \\
1990 \text {-es } \\
\text { százalékában } \\
(\%) \\
\end{array}$} \\
\hline & 1990 & 2000 & 2010 & & 1990 & 2000 & 2010 & \\
\hline Baranya megye & 1373744 & 1245648 & 783473 & $57,00 \%$ & 66715 & 50899 & 44233 & $66,30 \%$ \\
\hline Somogy megye & 1541656 & 1289411 & 983382 & $63,80 \%$ & 69368 & 54351 & 52061 & $75,10 \%$ \\
\hline Tolna megye & 768257 & 689150 & 495322 & $64,50 \%$ & 41113 & 34562 & 29654 & $72,10 \%$ \\
\hline Dél-Dunántúl & 3683657 & 3224209 & 2262177 & $61,40 \%$ & 177196 & 139812 & 125948 & $71,10 \%$ \\
\hline Magyarország & 35905068 & 34495572 & 26537087 & $73,90 \%$ & $\begin{array}{c}148595 \\
7\end{array}$ & 1359024 & 1539928 & $103,60 \%$ \\
\hline
\end{tabular}

Forrás: KSH évkönyvek (1990, 2000, 2010) alapján saját szerkesztés, 2012

Jelentős volt a kikölcsönzött könyvtári egységek számának 40\%-os csökkenése (10. táblázat). Bár a Dél-Dunántúlon Pécs tekinthető a legnagyobb kulturális központnak, de itt is csökkenés volt tapasztalható kölcsönzés terén, illetve a beiratkozottak számának tekintetében.

\section{1. táblázat: Könyvtári ellátottság a Dél-Dunántúlon - 2010}

\begin{tabular}{|c|c|c|c|c|c|c|c|c|}
\hline & \multirow{2}{*}{$\begin{array}{c}\text { Települések } \\
\text { száma }\end{array}$} & $\begin{array}{c}\text { rendelkezõ } \\
\text { település }\end{array}$ & $\begin{array}{c}\text { Kem } \\
\text { rendelkezön } \\
\text { település }\end{array}$ & $\begin{array}{c}\text { Lakosság } \\
\text { száma (fö) }\end{array}$ & $\begin{array}{c}\text { kōnyvtárak } \\
\text { száma }\end{array}$ & $\begin{array}{c}\text { állomány } \\
\text { száma }\end{array}$ & $\begin{array}{c}\text { kölcsönzött } \\
\text { állomány } \\
\text { száma }\end{array}$ & $\begin{array}{c}\text { 10000 lakosra jutó } \\
\text { beiratkozot- } \\
\text { tak száma }\end{array}$ \\
\hline Baranya megye & 301 & 250 & 51 & 393758 & 6,27 & 49244 & 19897 & 1123 \\
\hline Somogy megye & 245 & 230 & 15 & 320578 & 7,3 & 68834 & 30675 & 1624 \\
\hline Tolna megye & 109 & 107 & 2 & 233650 & 4,67 & 56688 & 21199 & 1269 \\
\hline Dél-Dunántúl & 655 & 587 & 68 & 947986 & 6,22 & 57704 & 23863 & $I 329$ \\
\hline Magyarország & 3154 & 2931 & 223 & 10014324 & 2,96 & 43722 & 26499 & $I 538$ \\
\hline
\end{tabular}

Forrás: KSH évkönyvek (2010) alapján saját szerkesztẻs, 2012

A régióról elmondható, hogy igen nagy a könyvtári lefedettség (11. táblázat), bár pont Baranya megye rendelkezik a legtöbb könyvtárral nem rendelkező településsel. (BudaySántha A. 2011)

\section{5. ÖSSZEFOGLALÁS}

Egy régió gazdaságát sok minden meghatározza. Vannak olyan tényezök, amiken nem lehet változtatni. A földrajzi elhelyezkedés többek közọtt az egyik ilyen tényező. A Dél- 
Dunántúl egy gazdaságilag elmaradott régió mind az Európai Unióban, mind pedig Magyarországon. Országos viszonylatban a gazdasági teljesítőképessége alacsony, ami sok tényezöre vezethető vissza. Mindenképp meg kell említeni a régió sajátos, heterogén településszerkezetét. Sok zsákfalu, aprófalú helyezkedik el a térségben. Rossz az infrastruktúra és a közlekedési útvonalak nem biztosítanak átvezetést az egyes települések között. Alacsony a népességszám és magas a munkanélküliségi ráta, alacsony a munkaerö kereslet és az elérhető munkabér. Ezek együttesen hatással vannak az oktatási helyzetre. Ennek tudatában egy hatékonyabb oktatáspolitika kialakítása lenne szükséges, hiszen a régiónak nagy múltja van e téren. Gazdag oktatási és kulturális múlttal rendelkezik, ami jó például szolgálhat, hogy hogyan kapcsolódjon be a térség az ország gazdasági, oktatási és kulturális vérkeringésébe.

\section{FELHASZNÁLT IRODALOM}

Buday-Sántha A. (2011): Dél-Dunántúli régió kutatás, TÁMOP - 4.2.1.B - 10/2/KONV 2010-0002, Munkaváltozat, PTE KTK Regionális Politika és Gazdaságtan Doktori Iskola, Pécs.

Központis Statisztikai Hivatal (1990): Területi Statisztikai Évkönyv, Központi Statisztikai Hivatal, Budapest.

Központis Statisztikai Hivatal (2000): Területi Statisztikai Évkönyv, Központi Statisztikai Hivatal, Budapest.

Központis Statisztikai Hivatal (2010): Területi Statisztikai Évkönyv, Központi Statisztikai Hivatal, Budapest. 